\title{
Post-pneumonectomy oesophageal fistula
}

\author{
J. P. EVANS \\ London Chest Hospital, London E2 9JX
}

The complication of oesophagopleural fistula is described in eight of 1,389 patients $(0.5 \%)$ who underwent pneumonectomy for carcinoma of the bronchus. All the patients had a right pneumonectomy performed and seven of the eight patients developed a bronchopleural fistula before developing an oesophageal fistula. The complication appeared between two weeks and 22 months after pneumonectomy. All the fistulae occurred on the right side; three were at the level of the bronchial stump and five were within $5 \mathrm{~cm}$ below the stump. The cause of the fistula was thought to be the development of a peribronchial abscess which ruptured into the oesophagus. The complication was diagnosed by the presence of food particles on the dressings in those patients with chest drains in situ. It was confirmed by Gastrografin swallow. The size of the fistulae varied between 3 and $8 \mathrm{~mm}$.

Successful immediate surgical closure of the fistula was accomplished in three patients. Feeding was continued using a gastrostomy.

Five patients unfit for surgery and treated by palliative measures died.

The development of a fistula between the oesophagus and the pneumonectomy space is a rare but serious complication of pneumonectomy. In a review of previous reports only 35 cases were found. Most of these occurred following pneumonectomy for tuberculosis or suppurative pulmonary disease (Muller, Byron, and Power, 1953 ; Pecora, 1958; Stander and Robinson, 1959; Takaro, Walkup, and Okano, 1960 ; DuMont and De Graef, 1961 ; Santos, Netto, and Marcal, 1964).

Takaro et al. (1960), in their review of 33 cases of oesophagopleural fistula following pneumonectomy for tuberculosis and suppurative pulmonary disease, reported a mortality rate of $49 \%$ with a cure rate of $21 \%$.

Only three reports, with a total of six cases, were found in which a fistula developed after pneumonectomy for carcinoma of the bronchus. Two cases were described by Eriksen in 1964. Three were reported by Benjamin, Olsen, and Ellis (1969). Engelman, Spencer, and Berg described a further one in 1970 . This communication describes the incidence and management of the condition at the London Chest Hospital.

\section{THE PATIENTS}

From 1951 to 1970 inclusive, 1,389 patients with carcinoma of the bronchus were treated by pneumonectomy. Eight of these patients $(0.5 \%)$ developed an oesophagopleural fistula.
The eight patients were men between 48 and 74 years of age. The diagnosis of carcinoma of the bronchus was confirmed preoperatively in each case by bronchoscopic biopsy. All the tumours were of the squamous-cell type and all were situated in the right lung. In each case their position was such that the only procedure that could be performed was right pneumonectomy. In six of the eight patients the bronchial stump was covered by a muscle graft. There was no histological evidence of metastases in the regional lymph nodes.

\section{DIAGNOSIS OF OESOPHAGOPLEURAL FISTULA AND TIME OF ONSET}

The criteria for accepting a diagnosis of oesophagopleural fistula were contamination of the dressings by particles of food and demonstration of the fistula on Gastrografin swallow.

Seven patients developed a bronchopleural fistula before developing an oesophageal fistula $\mathcal{O}^{\circ}$ (Table I). Four patients developed a broncho- N pleural fistula between one week and one month N after pneumonectomy. The three other patients developed a bronchopleural fistula between one and two months after pneumonectomy.

Four patients had a second thoracotomy with amputation of the bronchial stump and closure of the fistula, but in two the bronchopleural fistula recurred and was treated by tube drainage of the pneumonectomy space.

The other three patients who developed 
T A B LE I

\begin{tabular}{|c|c|c|c|c|c|c|c|}
\hline Patient & Age & Pneumonectomy & $\begin{array}{l}\text { Bronchopleural } \\
\text { Fistula }\end{array}$ & $\begin{array}{l}\text { Other Operative } \\
\text { Procedures }\end{array}$ & Outcome & \multicolumn{2}{|c|}{$\begin{array}{l}\text { Oesophagopleural } \\
\text { Fistula }\end{array}$} \\
\hline $\begin{array}{l}1 \\
2\end{array}$ & $\begin{array}{l}54 \\
53\end{array}$ & $\begin{array}{l}11 \text { Feb. } 1951 \\
23 \text { Aug. } 1961\end{array}$ & $\begin{array}{r}21 \text { Feb. } 1951 \\
6 \text { Sept. } 1961\end{array}$ & $\begin{array}{l}\text { Insertion of tube drain } \\
\text { Bronchopleural fistula } \\
\text { closed }\end{array}$ & & $\begin{array}{l}23 \text { Mar. } \\
14 \text { Mar. }\end{array}$ & $\begin{array}{l}1951 \\
1962\end{array}$ \\
\hline $\begin{array}{l}3 \\
4\end{array}$ & $\begin{array}{l}48 \\
63\end{array}$ & $\begin{array}{l}10 \text { Oct. } 1961 \\
17 \text { Mar. } 1964\end{array}$ & 29 Mar. 1964 & $\begin{array}{l}\text { Bronchopleural fistula } \\
\text { closed }\end{array}$ & $\begin{array}{l}\text { Bronchopleural fistula } \\
\text { recurred } 18 \text { Apr. } \\
\text { 1964. Tube drain } \\
\text { inserted }\end{array}$ & $\begin{array}{l}25 \text { Oct. } \\
29 \text { Apr. }\end{array}$ & $\begin{array}{l}1961 \\
1964\end{array}$ \\
\hline 5 & 57 & 14 Jan. 1966 & 8 Mar. 1966 & $\begin{array}{l}\text { Bronchopleural fistula } \\
\text { closed }\end{array}$ & $\begin{array}{l}\text { Bronchopleural fistula } \\
\text { recurred } 18 \text { Mar. } \\
\text { 1966. Tube drain } \\
\text { inserted }\end{array}$ & 15 Sept. & 1966 \\
\hline $\begin{array}{l}6 \\
7\end{array}$ & $\begin{array}{l}74 \\
52\end{array}$ & $\begin{array}{l}14 \text { Feb. } 1968 \\
15 \text { July } 1969\end{array}$ & $\begin{array}{l}18 \text { Mar. } 1968 \\
19 \text { Aug. } 1969\end{array}$ & $\begin{array}{l}\text { Insertion of tube drain } \\
\text { Bronchopleural fistula } \\
\text { closed }\end{array}$ & & $\begin{array}{l}16 \text { Jan. } \\
23 \text { Aug. }\end{array}$ & $\begin{array}{l}1970 \\
1970\end{array}$ \\
\hline 8 & 60 & 6 Mar. 1970 & 1 Apr. 1970 & Insertion of tube drain & & 4 May & 1970 \\
\hline
\end{tabular}

The patients were all male. All the tumours were of the squamous-cell type and situated in the right lung.

bronchopleural fistula were treated only by tube drainage of the space.

The oesophageal fistulae in this series developed 1 to 22 months after the bronchopleural fistulae. Three patients developed a fistula after one month. Two patients developed a fistula after six months, another two developed the complication 12 and 22 months after operation.

The only patient who did not develop a bronchopleural fistula developed his oesophageal fistula two weeks after pneumonectomy. This patient was one of the three to survive the complication.

The diagnosis of the complication was easy in patients whose bronchopleural fistula was being treated by tube drainage. The onset of the complication was heralded by contamination of the dressings by particles of food. Radiographs of the oesophagus after Gastrografin swallow were then taken to confirm the diagnosis and to determine the site and size of the fistula.

In the three patients who did not have pleural drainage at the time, the onset of the complication was indicated by fever, leucocytosis, and pain in the chest. A chest radiograph showed no change in the size of the air pocket but needle aspiration of the pneumonectomy space revealed the presence of Gram-negative organisms. A Gastrografin swallow was carried out and confirmed the presence of the fistula. All the cases in this series were diagnosed during life.

\section{SITE AND SIZE OF FISTULA}

Each fistula, as demonstrated by Gastrografin, was in close proximity to the bronchial stump. All communicated with the right pleura. Three were at the level of the bronchial stump. Five were situated 3 to $5 \mathrm{~cm}$ caudad to the level of the stump. The size of the fistula noted on the radiograph varied between 3 and $8 \mathrm{~mm}$ in diameter.

\section{TREATMENT AND RESULTS}

Three patients survived the complications and are still alive. One patient has survived for 10 years, the second for three years, and the third patient has survived for two years.

These patients were all treated in the first instance by needle aspiration of the pneumonectomy space and instillation of antibiotics followed within 24 hours by operative closure of the fistula and the formation of a gastrostomy. The oesophageal repair was carried out in two layers using chromic catgut. In one patient a seven-rib thoracoplasty was also carried out to obliterate the space and control the infection. Postoperatively all three patients had antibiotics injected daily into the pneumonectomy space until the pleural fluid was sterile.

The organisms cultured from the pleural fluid were predominantly Escherichia coli, streptococci, and staphylococci. The antibiotic used depended on sensitivities but ampicillin was most commonly used. It was given in a dose of $1.0 \mathrm{~g}$ per day until the pleural fiuid was found to be sterile, on average after seven days of treatment.

Five patients died of the complication. Death occurred between three days and two months after the fistula was diagnosed.

Two patients were treated by gastrostomy. In the remaining three, gastric feeding was carried out using a Ryle's tube. All had daily instillation of the appropriate antibiotic into the pneumonectomy space but sterilization of the pleural fluid was never achieved. 
T A B L E I I

OESOPHAGOPLEURAL FISTULAE

\begin{tabular}{|c|c|c|c|c|c|}
\hline Patient & Site & Size $(\mathrm{mm})$ & Operation & Other Measures & Outcome \\
\hline $\begin{array}{l}1 \\
2 \\
3 \\
4 \\
5 \\
6 \\
7 \\
8\end{array}$ & $\begin{array}{l}5 \mathrm{~cm} \text { below stump } \\
\text { At stump } \\
3 \mathrm{~cm} \text { below stump } \\
3 \mathrm{~cm} \text { below stump } \\
\text { At stump } \\
\text { At stump } \\
5 \mathrm{~cm} \text { below stump } \\
4 \mathrm{~cm} \text { below stump }\end{array}$ & $\begin{array}{l}4 \\
5 \\
3 \\
8 \\
5 \\
4 \\
4 \\
6\end{array}$ & $\begin{array}{l}\text { None } \\
\text { None } \\
\text { Direct closure with 7-rib thoracoplasty } \\
\text { None } \\
\text { None } \\
\text { Direct closure } \\
\text { Direct closure } \\
\text { None }\end{array}$ & $\begin{array}{l}\text { Gastrostomy } \\
\text { Gastrostomy } \\
\text { Gastrostomy } \\
\text { Feeding by Ryle's tube } \\
\text { Feeding by Ryle's tube } \\
\text { Gastrostomy } \\
\text { Gastrostomy } \\
\text { Feeding by Ryle's tube }\end{array}$ & $\begin{array}{l}\text { Died after } 23 \text { days } \\
\text { Died after } 54 \text { days } \\
\text { Alive after } 10 \text { years } \\
\text { Died after } 17 \text { days } \\
\text { Died after } 3 \text { days } \\
\text { Alive after } 3 \text { years } \\
\text { Alive after } 2 \text { years } \\
\text { Died after } 3 \text { days }\end{array}$ \\
\hline
\end{tabular}

The condition of the five patients at the time of the complication was so precarious that operative closure of the fistula was not contemplated. It was hoped that the measures taken would allow operative closure at a later date.

Permission for necropsy was refused by relatives of those patients who died.

\section{DISCUSSION}

The two most common causes of oesophagopleural fistula after pneumonectomy are operative injury and infection (Takaro et al., 1960). The fistula that arises after operative injury occurs within a few days of the operation (Takaro et al., 1960). It may be due to direct instrumental injury of the oesophagus at operation by stripping of the subcarinal nodes, or to damage to the blood supply of the wall of the oesophagus (Benjamin et al., 1969).

Oesophageal fistula occurring three months or longer after operation has been attributed to chronic infection (Takaro et al., 1960). The causes of a fistula of late onset are rupture into the oesophagus of a perioesophageal or peribronchial abscess (Muller et al., 1953), the presence of a suppurating lymph node rupturing through the wall of the oesophagus, or direct inflammatory involvement of the wall and recurrence of the original tumour (DuMont and De Graef, 1961 ; Eriksen, 1964 ; Benjamin et al., 1969 ; Engelman et al., 1970). In the present series, infection of the bronchial stump was probably a potent source of infection as seven of the eight patients first developed a bronchopleural fistula.

The majority of oesophageal fistulae appearing after pneumonectomy occur at mid-oesophageal level. This could be explained by the presence of tumour-involved lymph nodes in and about the carinal and sub-carinal area. This was the level at which perforations of the oesophagus by tuberculous lymph nodes have most commonly been noted (Frostad, 1959).
DuMont and De Graef (1961) stated that the blood supply of the oesophagus is segmental and that the oesophagus caudal to the carina has af poorer supply than the remainder. This bloof supply is shared with other structures in the mediastinum, notably the glands. They sugges? that any damage at the time of operation mighs result in ischaemic necrosis of the oesophagea wall.

Fistula formation has been found to involve the right pleural cavity in $88 \%$ of cases (Mullek et al., 1953 ; Pecora, 1958 ; Stander and Robin ${ }^{\text {- }}$ son, 1959; Takaro et al., 1960 ; DuMont and DE Graef, 1961 ; Eriksen, 1964 ; Santos et al., 1964 క Benjamin et al., 1969; Engelman et al., 1970)흥 This is explained by the anatomy of the oesoo phagus. On the left side the oesophagus is separated from the pleura by the aorta through $\overrightarrow{0}$ out the greater part of its course. On the right side the oesophagus is in close proximity to the pleura? The oesophagus is therefore more likely to be injured by operative procedures on the right that on the left side. All the patients in this report ha $\Phi$ a right-sided fistula.

High fever and tenderness of the chest on palo pation would suggest the presence of an empyem?. which always accompanies oesophagopleura\$ fistula.

Leucocytosis, gross sepsis, and Gram-negative organisms in the pleural fluid are other signs to be looked for. The presence of food particles on the dressings are pathognomic if there is a drain age tube in situ. Confirmation of the presence of a fistula can be obtained by radiography following the oral administration of Gastrografin. Thiङ method is also necessary to localize the position of the fistula and to determine its size (Benjamic et al., 1969). Eriksen (1964), in his two cases whic did not have pleural drains, confirmed the diage nosis by finding saliva and particles of orat mucosa in the pleural aspirate.

Direct closure of the oesophageal fistula, whilg often not curative, is considerably safer tha extensive oesophageal reconstruction procedure 
using stomach, jejunum or colon (Takaro et al., 1960).

Benjamin et al. (1969) suggested that the suture repair should be covered with a pleural flap. Success was achieved by the instillation of neomycin into the pleural space in the postoperative period. Thoracoplasty was not performed in any of his cases and all three patients survived.

Engelman et al. (1970) considered that, with the large $(5 \mathrm{~cm})$ defect in the oesophagus present in his patient, obliteration of the pneumonectomy space was essential in order to control infection and prevent recurrence of the fistula. He also felt that a muscle graft applied over a single layer of catgut sutures would prevent the development of an oesophageal stricture which might occur if such a large defect were closed in two layers.

Postoperative instillation of antibiotics into the pneumonectomy space is essential to sterilize the infected space once the cause of the fistula has been removed. It should be carried out daily until the pleural fluid is sterile (Sturridge, 1964 ; Bryant, Spencer, and Trinkle, 1969; Engelman et al., 1970).

The five patients who died were so ill that no immediate repair of the fistula was contemplated and they were treated by daily instillation of antibiotics into the pneumonectomy space, combined with gastrostomy in two cases and gastric feeding using a Ryle's tube in the other three. The high mortality in this group confirms the findings of Takaro et al. (1960) that, in those patients in whom no definitive surgical treatment is carried out, the mortality approaches $100 \%$.

\section{CONCLUSIONS}

Oesophagopleural fistula is an uncommon but important complication of pneumonectomy for carcinoma of the bronchus. The only hope of a successful outcome is early recognition of the condition by a Gastrografin swallow. Early surgical closure of the defect is mandatory. Thora- coplasty may be used to obliterate an infected pneumonectomy space. All patients should have daily instillation of appropriate antibiotics into the pneumonectomy space until the pleural fluid is sterile. There is no justification for palliative procedures such as drainage of the empyema space, gastrostomy or jejunostomy.

I should like to thank the consultant surgeons at the London Chest Hospital for allowing me to study the case reports of patients under their care. I should also like to thank Mr. M. F. Sturridge for his advice and encouragement in the writing of this paper.

\section{REFERENCES}

Benjamin, I., Olsen, A. M., and Ellis, F. H. (1969). Oesophagopleural fistula; a rare postpneumonectomy complication. Ann. thorac. Surg., 7, 139.

Bryant, L. R., Spencer, F. C., and Trinkle, J. K. (1969). Treatment of median sternotomy infection by mediastinal irrigation with an antibiotic solution. Ann. Surg., $169,914$.

DuMont, A., and De Graef, J. (1961). La fistule oesophagopleural, complication tardue de la pneumonectomie. Lyon chir., 57, 481.

Engelman, R. M., Spencer, F. C., and Berg, P. (1970). Postpneumonectomy esophageal fistula; successful one stage repair. J. thorac. cardiovasc. Surg., 59, 871.

Eriksen, K. R. (1964). Oesophagopleural fistula diagnosed by microscopic examination of pleural fluid. Acta chir. scand., 128, 771.

Frostad, S. (1959). Segmental atelectasis in children with primary tuberculosis. Amer. Rev. Tuberc., 79, 597.

Muller, W. H., Byron, F. X., and Power, H. W. (1953). Delayed traumatic rupture of the esophagus. J. thorac. Surg., 25, 371.

Pecora, D. V. (1958). Tuberculous fistula of the esophagus. J. thorac. Surg., 36, 53.

Santos, M. I. Dos, Netto, S. M., and Marcal, O. (1964). Fistula esofagopleural traumática postpneumonectomia. Análise de um caso tratado por esofagogastroplastia retrosternal. Rev. paul. Med., 65, 263.

Stander, L. H., and Robinson, H. H. (1959). Spontaneous esophageal cutaneous fistula. Amer. Surgn, 25, 248.

Sturridge, M. F. (1964). M.S. Thesis, University of London.

Takaro, T., Walkup, H. E., and Okano, T. (1960). Esophagopleural fistula as a complication of thoracic surgery. J. thorac. cardiovasc. Surg., 40, 179. 